\title{
Pin-retain for restoration of widely tooth damaged
}

Ira Widjiastuti

Department of Conservative Dentistry

Faculty of Dentistry, Airlangga University

Surabaya - Indonesia

\begin{abstract}
ABTRACT
Widely damaged tooth involves enamel as well as dentin could be due to caries or other causes, resulted the preparation of retention could not be fulfilled so that additional pin is used as retention. Pin is made of titanium and used as retention for restoration with the aim to unite restorative material in tooth cavity by filling the hole that is prepared in the dentin. The number of pins that are needed is according to the width of the lost tooth tissue. Restoration with pin functions as retention has conservative advantage to the tooth structure, increases retention, resistance, period of treatment is short, and the cost is cheaper.
\end{abstract}

Key words: retention, pin, restoration

Correspondence: Ira Widjiastuti, c/o: Bagian Konservasi Gigi, Fakultas Kedokteran Gigi Universitas Airlangga. J1. Mayjend. Prof. Dr. Moestopo 47 Surabaya 60132

\section{INTRODUCTION}

Restoration failure can be due to various factors in which one of them is releasing restoration because of lack of retention. Wide loss of tooth structure involves enamel and dentin causing insufficient resistance and retention consequently releasing restoration or fracture of tooth structure might occur. ${ }^{1}$ To reach good restoration, a dentist should be able to determine the tooth structure that should be preserved or evacuated so that the tooth could be well restored, the restoration is not easily released and the residual of tooth tissue would be resistant to mastication forces. Box, undercut, or grove retention could not be made when tooth damage is widely. In this case, pin is needed as retention to avoid releasing restoration and residual of tooth tissue is strong to resist mastication forces. Pin placement is intended to attach restorative material on tooth cavity that has been prepared and the number of pins that are needed should be according to the width of the lost tooth tissue. Pin placement is performed as alternative consideration to conserve tooth vitality and to prevent extended disease. Restoration with pin as retention can be done in one visit. Furthermore, the cost is more economical compared to extra or intra indirect restoration coronal with alloy material. ${ }^{2}$

\section{The use of pin}

The use of pin on restoration is to unite restorative material with the prepared tooth and to increase retention. The use of pin in excessive number will weaken the strength of restoration toward mastication, therefore to obtain restoration with pin retention requiring the number of pin in accordance with the width of tooth damage. ${ }^{2}$ The use of excessive number of pins can cause the distance of pin smaller therefore the compression of restorative material into the cavity will be difficult, dentin will be easily fracture and broken so that the restoration is not strong enough to bear mastication forces.

Some factors that influence pin retention are type, surface form, parallel or bending, and the number of pin. Pin gives retention and relatives retention value. The number of inserted pin should be in accordance with the necessity. One pin is needed for every missing cusp and for every missing proximal tooth structure. ${ }^{1}$

\section{Types of pins and techniques for pin insertion}

In tooth with large damage, the pin that will be used is inserted into dentin hole which has been prepared. Pin is made of stainless steel that polished with gold and gradually pin is made of titanium. ${ }^{2}$ In general, there are two types of pin: non-parallel and parallel pin. ${ }^{3}$ The pin that is frequently used and easily inserted is non parallel pin (Figure 1). There are three types of non parallel pins: cemented pin, friction-locked pin (Unitek) and self-threading pin (TMS, Whaledent ). This type of pin is frequently used. $1,2,3$

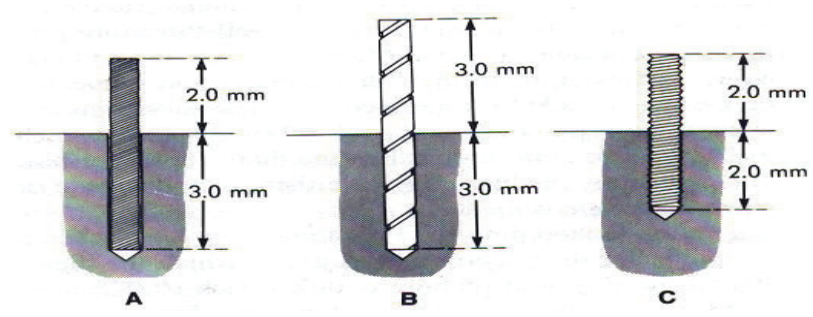

Figure 1. Various non-parallel pin. (A) Cemented pin, (B) Friction locked pin, (C) Selfthreading pin.

Cemented pin is a pin that inserted by cementation. The pin surface is serated and inserted into pinhole with diameter 0,001-0,002 inch $(0,025-0.05 \mathrm{~mm})$ larger than 
the diameter of the pin. Friction-locked pin (Unitek) is a pin that implanted by taped to place. Pin is inserted into pinhole with diameter 0.001 inch or $0.025 \mathrm{~mm}$ smaller than the diameter of the pin. Retention of this pin depends on the resiliency of dentin. Self threading pin (TMS, Whaledent) is a type of pin which inserted by screwing. Pin is inserted into the pinhole with diameter $0.038-0.1 \mathrm{~mm}$ smaller than pin diameter, retention is made by gripping and depends on resiliency of dentin. Stabilok pin is self-threading pin that combined in the form of screw bur design, in which pin is united with latch type mandrel (mandrel pin) which can be implanted on contra angel hand piece. The diameter of small pin is $0.021 \mathrm{~mm}$ (yellow), while medium pin is $0.027 \mathrm{~mm}$ (orange) that available in a kit completed with twist drill.

Tooth with wide damage and residual tissue is not strong enough such as: lost one or two of cusps, in order to achieve optimal retention the tooth should prepared in the form of cavity of pulp wall and gingival wall forming perpendicular angle, making axial split, while gingival wall is not enlarged in sub gingival. ${ }^{2}$ The requirement to obtain restorative result with pin as additional retention is thick dentin should be available (dentin thickness is $1.5 \mathrm{~mm}$ between pin and enamel surface and root) perpendicular and parallel with tooth axial. The part of pin on tooth surface is $2 \mathrm{~mm}$ and the thickness of restorative material is $2 \mathrm{~mm}$ between the tip of pin with occlusal surface of restorative material (Figure 2-A).

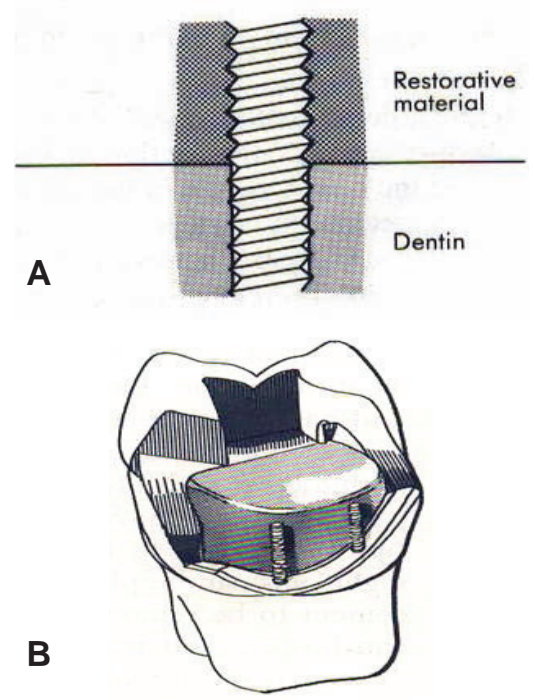

Figure 2. Location of pin. ${ }^{2}$

(A) Pin position in dentin, (B) Pin position for cavity.

Before inserting the pin, pinhole should be made in dentin by using depth limiting twist drill and could be inserted according to the type of the pin. To decide the pinhole, some factors should be considered such as pulp anatomy, the contour of tooth surface (convex or concave), dentin thickness, periodontal pocket, and the age of patient. Pinhole should be placed on the flat surface and half of the distance between outer part of tooth and pulp. Pin insertion should be required $0.5 \mathrm{~mm}$ from axial wall and $0.5 \mathrm{~mm}$ from dentino-enamel junction or the root surface, far from tooth bifurcation, parallel with tooth outer surface in order to prevent from effecting periodontal tissue, located in restorative material mass, and closed to proximal line (one pin per one missing cusp) (Figure 2-B).

Performing pin insertion in tooth, tooth anatomy should be paid closed attention. Prominensia concavity is found on the middle part of upper first molar, pulp horn in mesio buccal side is found on the upper and lower first molar, on the lower first and second molar found convexity on mesial and buccal side while molar teeth are found on buccal, mesial and distal side. This condition should be seriously considered otherwise restoration failure might happen such as: the occurrence of perforation either on the pulp or periodontal tissue. , $^{2,4}$

After pin insertion has been completed, it is continued by manipulation using restorative material while amalgam, resin composite ${ }^{4}$ can be used as restorative material. If proximal contact is opened, matrix band and wedge are obligatorily by used and if multiple cusp has lost, greenstick might be applied to achieve matrix stabilization. ${ }^{4}$ By the development of science, pin implantation is combined by giving adhesive material to increase restoration strength.

\section{Treatment and prognosis}

To forming restoration on vital tooth with pin retention, tooth condition should be paid closed attention. If caries in the dentin is found and remains in thin layer, pulp capping is the first thing to be done. Further treatment is done to release symptomatic preoperative complaint to avoid the increase of sensitivity and prolonged complaint. ${ }^{2,3,5}$ On posterior tooth with crown damage affected more than one cusp which is classified as total damage required complex restoration treatment, and the use of pin as retention should be considered in order to keep pulp vitality which means the treatment is more conservative and the prognosis is good (Figure 3). 6,7
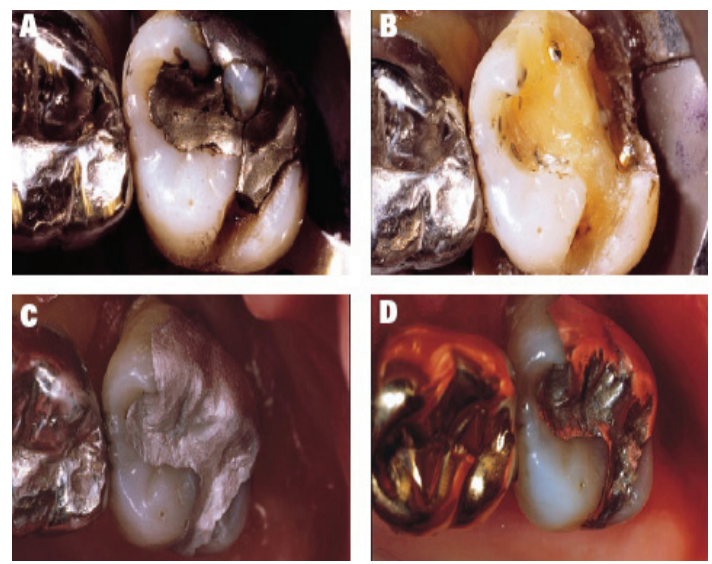

Figure 3. Pin retaine for complex restoration. ${ }^{7}$ (A) Before treatment, (B) Tooth preparation, and pin inccertion, (C) After restoration, (D) After used for 5 years. 


\section{DISCUSSION}

The effort of performing tooth restoration is one of the efforts to conserve the tooth in oral cavity, to maintain the function for mastication, phonetic, and aesthetic according to stomatognatic function. It's difficult to achieve good retention for vital tooth with widely lost hard structure tissue affecting enamel and dentin due to caries or other causes, so additional retention is required by using pin which is inserted in dentin and compressed restorative material in adjacent area. ${ }^{1}$

Pin is the alternative to increase retention of restored tooth with the loss of the one cusp even with totally damaged crown and to preserve the pulp vitality so the restoration of tooth with the loss of more than one cusp can be done only in one visit. Meanwhile in tooth with totally damaged crown, $\mathrm{x}$-ray radiograph is needed to know the thickness of dentin and if the thickness is adequate $(1.5 \mathrm{~mm})$ pin can be used as additional retention so pulp vitality can be preserved and the tooth is restored by using composite resin or amalgam as the core, finally followed by crown restoration. ${ }^{2,5}$

Pin hole preparation is conservative treatment compared with slot and lock as well as tooth preparation for indirect extra or intra coronal restoration with alloy due to more dentin tissue evacuation. Pin insertion into cavity increase retention and resistance, further more the treatment can be done one visit, relatively inexpensive, and suitable for elderly patient or patient with mental trouble. ${ }^{2}$

To increase retention of restorative material in tooth cavity, before pin insertion, cavity wall should be polished by adhesive material. Uyera et al. ${ }^{6}$ and Davis \& Overton $^{8}$ suggested that the combination between dentin adhesive material and pin insertion can give better strength compared with giving pin only or dentin adhesive material only. Rosen ${ }^{9}$ suggested that tooth with amalgam complex restoration will be stronger if prior to filling should be polished with bonding agent and pin is used as additional retention. Bonding material will either chemically or physically attach the dentin finally will mechanically attach restorative amalgam so it will increase attachment strength and will reduce the possibility of leakage in the edge part of amalgam restoration. ${ }^{10}$

Pin as an additional retention is rarely used for composite resin restoration in anterior tooth due to etch technique and bonding, however in the case of tooth with widely damaged crown in class VI cavity, it is necessary to perform additional retention to stabilize restoration besides the treatment can be done only in one visit. ${ }^{2}$

Pin which is used as additional retention can keep the structure of tooth tissue without excessive evacuation of dentin tissue, therefore restoration can be done in widely damaged crown, pulp vitality can be restored, retention factor and tooth resistance will increase, period of treatment will be short. The cost of treatment will be unexpensive compared to indirect extra or intra coronal restoration using either alloy or porcelain.

\section{REFERENCES}

1. Baum L, Phillips RW, Lund MR. Buku ajar ilmu konservasi gigi. Edisi ke-2. Jakarta: EGC; 1995. p. 456-86.

2. Sturdevant CM, Roberson TM, Heyman HO, Sturdevant JR. The art science of operative dentistry $3^{\text {rd }}$ ed. St Louis, Toronto, Priceton: The CV Mosby Company; 1995. p. 504-12.

3. Howard WW. Atlas of operative dentistry. $2^{\text {nd }}$ ed. St. Louis: The CV Mosby Company; 1973. p. 141-6.

4. Wassel RW, Smart ER, George ST. Crowns and other extra coronal restoration: Cores for teeth with vital pulps. Br Dent J 2002; 192:499-509.

5. Soetanto S. Perbedaan kekuatan tarik pin ulir pada dentin dengan cara pemasangan menggunakan hand piece putaran rendah dan uliran tangan. Maj. Ked. Gigi (Dent J) 1995; 29:135-8.

6. Uyehara MY, Davis RD, Overton JD. Cuspal reinforcement in endodontically. J Op Dent 1999; 24:364-70.

7. Summit JB, Burgeess JB, Berry TG, Robbins JW. The performance of bonded vs. pin retained complex amalgam restorations. A five year clinical evaluation. J Am Dent Assoc 2001; 132:923-31.

8. Davis RD, Overton JD. Efficacy of bonded and non bonded amalgam in the treatment of teeth with incomplete fractures. J Am Dent Assoc 2000; 131:469-78.

9. Rosen AT. Resistance of bonded complex amalgam restoration with and without pins. J Dent Res 1998; 77:153.

10. Setcos JC, Staninec M, Wilson NHF. The development of resin bonding for amalgam restorations. Br Dent J 1999; 186:328-32. 